\title{
Use of Antiviral Virucides in the Prevention of Some Viral Diseases Causing on Tobacco Plants in Vietnam
}

\author{
Nguyen Van Chin ${ }^{1 *}$, Nguyen Van Van ${ }^{1}$, Tào Ngọc Tuấn ${ }^{1}$, Dương Xuân Diêu ${ }^{2}$, Phạm Hà Thành ${ }^{3}$, \\ Phung Thi Hay ${ }^{4}$, and Nguyen Van Cuong ${ }^{4}$ \\ ${ }^{1}$ Vietnam Tobacco Institute \\ Ha Noi, Vietnam \\ ${ }^{2}$ Ministry of Industry and Trade \\ Hanoi, Vietnam \\ ${ }^{3}$ Vietnam Tobacco Corporation \\ Ha Noi, Vietnam \\ ${ }^{4}$ Branch of Tobacco Institute in Bac Giang provice \\ Vietnam \\ *Corresponding author's email: chinvtl [AT] gmail.com
}

\begin{abstract}
In recent years, some viral diseases have been increasing in the tobacco-growing regions of Vietnam and cause serious damage to the tobacco yield and quality. If it has not an effective control, viral diseases will injure seriously in the tobacco field in next time. To control the effect of viral diseases, study use of some antiviral virucides is necessary on tobacco plants. In 2021, Vietnam Tobacco Institute experimented with the effective control of Ditacin 8SL, Sat 4SL, and Exin 4.5SC for TMV, CMV, PVY, and TNRV on the tobacco field in Bac Giang province. Results of the study show the antiviral agents are effective in the control of the virus disease on tobacco. When only spray Ditacin 8SL, effective prevention for viral diseases ranges from 22.4 - 30.3\%; Sat 4SL: 5.5 - 30.2\%, and Exin 4.5SC: 8.2 - 24.1\%. Spraying a mixture of antiviral agents and insecticides gives higher efficiency than spraying a kind. For example, spray Ditacin 8SL + Confodor 100SL, effective control reaches from 34.3 to 100\%; Sat 4SL + Confidor 100SL: 32.6 - 92.3, and $38.5-100 \%$ with Exin 4.5SC + Confidor 100SL. The spray treatments have a higher yield and quality than the control without spraying.
\end{abstract}

Keywords ---- Disease, tobacco, viral disease, antiviral agent, virucides

\section{INTRODUCTION}

Viral diseases often threaten the sustainable development of agricultural production in the world. They infect a lot of crop species and estimated annual losses worldwide of about $\$ 600$ billion. Tobacco mosaic virus (TMV), the type member of the Tobamovirus genus, is a prevalent plant pathogen all over the world and has the widest host range of over 885 plant species in 65 families. TMV has infected some economically important crops and caused significant economic losses worldwide (Ziwen Wang et al., 2012). Potato virus Y (PVY) belongs to a group of the most important potato viruses infecting the potato, tobacco, pepper, tomato, and is transmitted by aphids. PVY can causes major yield losses of up to reach 100\% in tobacco (Florence Faurez et al., 2012). For cucumber mosaic virus (CMV), it is a member of one of the most important virus families, Bromoviridae, which can infect at least 1.200 susceptible species in more than 100 plant families including crops, fruits, vegetables, ornamentals, woody plants, and other economically important plants worldwide. CMV can cause severe systemic mosaic symptoms such as leaf distortion, systemic necrosis, chlorosis, dwarfism, and reduce servere yield tobacco. CMV is transmitted by at least 80 aphid species in a non-persistent manner (Boualem et al., 2016 and Palukaitis et al., 2003). Tomato necrotic ringspot virus (TNRV) belongs to he genus Tospovirus, family Bunyaviridae includes plant viruses that infect a wide range of plant species including vegetable, fruit and ornamental crops (German TL et al., 1992). TNRV is first discovered on the tobacco plants in Vietnam in 2019 (Nguyen Van Chin et al., 2021), tomato in Thailand in 2011 (Channarong Seepiban et al., 2011) and China in 2014 (Yueyan Yin, et al., 2014), and tomato in Việt Nam, 2020 (Hoseong Choi et al., 2020). Tomato necrotic ringspot virus is transmitted by thrips.

The prevention of viral diseases that harm crops with chemical agents is impossible because they are species that are a parasite the cell. Using chemicals only have the effect of inhibiting the development of virus leads to reduce disease symptoms in the plants. There are no control measures to inhibit plant viruses after they have infected into plants. Currently, some chemicals can prevent the development of viruses such as Ningnanmycin (NNM), Cytosinpeptidemycin, Salicylic acid (SA), Flavonoid, Terpenes. In there, Ningnanmycin, Cytosinpeptidemycin và Salicylic acid have been using widely in China to control some viral diseases on the tobacco plants and others. Ningnanmycin, the most successful registered 
antiplant viral agent, displayed $56,0 \%$ in vivo curative effect at $500 \mu \mathrm{g} / \mathrm{mL}$. For TMV, the effective control of NNM is over $56 \%$ when spraying at a dose of $500 \mu \mathrm{g} \mathrm{mL}-1$ (Ziwen Wang et al. 2012). Salicylic acid (SA) induces resistance to Cucumber mosaic virus (CMV) in tobacco (Nicotiana tabacum) results from inhibition of systemic virus movement and is induced via a signal transduction pathway that also can be triggered by antimycin $\mathrm{A}$, an inducer of the mitochondrial enzyme alternative oxidase (AOX). Cytosinpeptidemycin (CytPM) is a microbial pesticide that displayed broad-spectrum antiviral activity against various plant viruses. CytPM could effectively delay the systemic infection of tobacco mosaic virus (TMV) in Nicotiana benthamiana and significantly inhibit the viral accumulation in tobacco BY-2 protoplasts. Results of RNAseq indicated that 210 and 120 differential expressed genes (DEGs) were significantly up and down-regulated after CytPM treatment in BY-2 protoplasts, respectively (Mengnan An et al. 2019). Result of study in Bac Giang province, Vietnam, 2020 showed, in net-house condition, tobacco plants treated the Ditacin 8SL from 3 to 6 times before infected plants had effective control of the PVY with ranging from $24-33 \%$, TMV: 28,9-50\%, and CMV: 42,6 - 60\% after 21 days of inoculation; For the Sat 4SL, effective control of TMV ranged from 23,7 - 31,6\%, CMV: 20,0 - 24,4\%, and PVY: 28,9 $35,6 \%$ after 21 days of inoculation. In the field condition, the effective control of NNM was 100\% for TMV, PVY: $93,5 \%$, CMV: $60,5 \%$, and TNRV: 52,1\%. Similar to Ditacin 8SL, treating Sat 4SL, the effective control of TMV reached 70,9\%, CMV: 58,3\%, PVY: 96,4\%, and TNRV: 36,9\%. Spraying Ditacin 8SL and Sat 4SL in the stage from transplanting (3 - 4 leaves/plant) to 16 - 18 leaves/plant were the best control of viral diseases, increased the yield, grade index, and less impact on the property of smoke (Nguyen Van Chin et al., 2021).

In recent years, some viral diseases have been increasing quickly in the tobacco-growing regions in Vietnam and cause more damage than some fungal, bacterial, and other diseases. They significantly harm the yield and quality of tobacco. In there, TMV, CMV, and PVY are the most common pests in the tobacco field of the northern Vietnam. Tomato necrotic ringspot virus is causing strong harm in Bac Giang province. For example, TMV occurred generally in the field in Cao Bang, Bac Kan, and Lang Sơn provinces with disease incidence ranging from 3,5\% to $90 \%$; CMV from $0,8 \%$ to 9,5\%; and PVY from $2,1 \%$ to $31,5 \%$, while TNRV caused severely damage in Bac Giang province with the disease incidence reaching 100\% (Nguyen Van Chin et al., 2021). To manage the effect of viral diseases on tobacco plants, study use of some antiviral virucides is necessary and significant practice for viral diseases on tobacco plants.

\section{MATERIALS AND METHODS}

\subsection{The study site}

The study is conducted in the Bac Giang province, Vietnam from January to June 2021. The experimental field station is annually infected from medium to severe level with some viral diseases of TMV, CMV, PVY, and TNRV.

\subsection{Material and object}

Using antiviral virucides with trade named as Ditacin 8SL (Ningnanmycin), Sat 4SL (Cytosinpeptidemycyn), and Exin 4,5SC (Salicylic acid) are tested in field conditions with the tobacco variety C9-1. Variety C9-1 is sensitive to some viral diseases on tobacco plants. Insecticide for control aphids and thrips transmitting virus on tobacco is Confidor 100SL (Imidacloprid).

\subsection{Study in the field condition}

Tobacco seeds of variety C9-1 are sown on a free pathogen nursery. The seedlings reach 4 - 6 leaves and plant them in the experimental field with a distance from the plant to another plant about $0.5 \mathrm{~m}$ and space between rows $1.1 \mathrm{~m}$, rate of fertilizers at $70 \mathrm{~N}: 140 \mathrm{P}_{2} \mathrm{O}_{5}: 210 \mathrm{~K}_{2} \mathrm{O} \mathrm{kg} / \mathrm{ha}$ with a form of $\mathrm{N}: \mathrm{NH}_{4} \mathrm{NO}_{3}$ and $\mathrm{K}: \mathrm{K}_{2} \mathrm{SO}_{4}$. Around the experiment is planted 3 - 4 rows of tobacco to protect the experimental field. The experiments are designed with a randomized complete block with three replications with two experiments: Spray virucides at a concentration from 1.0 - 2.5 times compared to the recommendation of the producer; Spray a mixture of virucide and insecticide. Spray pesticides every 6 days/a times from the transplanting stage to 16 - 18 leaves/plant and do not destroy infective plants.

\subsection{The target surveillance}

Surveying disease incidence and disease severity in the field is 10 days/times. Disease severity of PVY is assessed following to 6 levels of Arinaitwe Abel Byarugaba et al., 2020; TMV: 4 levels of Wang et al., 2009, and CMV: 5 levels of K. Nadarajah, N.M et al., 2009. The technical process of cultivation (planting, fertilizing, cultivating, watering), picking and curing according to the technical process of producing flue-cured tobacco following some standards of Vietnam and Coresta such as 10TCN 618 - 2005, Grade dry leaf tobacco: TCN 26-1-02, Smoking method: TC 01-2000. Analyzing chemical components follow standards of Vietnam and Coresta: Nicotine: TCVN 7103: 2002 (ISO 2881:1992), sugar: TCVN 7102: 2002, and Coresta: 38:1994. The effective control (EC\%): (1 - (Ta/Ca) x100), Ta: Disease severity index (disease index) of treatment after spraying virucide, and Ca: Disease severity index of control after spraying. Statistical analysis: Collected data is treated by Excel software and Statistix 8.2.

\section{RESULTS AND DISCUSSION}




\subsection{Effective control of antiviral virucides for TMV, CMV, PVY, and TNRV with difficult concentrations}

\section{- Ditacin 8SL (Ningnanmycin)}

Experimental results (table 1) show that Ditacin 8SL is effective in preventing and controlling potato virus $\mathrm{Y}$ (PVY), Tomato necrotic ringspot virus (TNRV), and cucumber mosaic virus (CMV). With the disease caused by PVY, tobacco plants treated with Ditacin 8SL have an effective control ranging from 30.3 to 53.8\%, an average of 41.1\%; CMV: $27.8-62.1 \%$ and an average $43.1 \%$. For TNRV, the effective control of Ditacin 8SL ranges from 22.4 to $63.8 \%$ and an average of $43.1 \%$. Spraying at a concentration of $2.0-2.5$ times is the highest control against PVY, CMV, and TNRV.

Increasing the concentrated treatments of Ditacin 8SL has the effect of increasing the disease resistance of tobacco plants against the infection and development of PVY, TNRV, CMV in the tobacco plant. Increased concentrations of Ningnanmycin will increase preventing infection of virus into plants lead to a decrease in disease incidence in the field. For example, when increasing the spray concentration from 1.0 time, 1.5 times, 2.0 times, and 2.5 times, the disease incidence of TNRV gradually decreases respectively from $55.7 \%, 45.3 \%, 37.4 \%$, and $34.5 \%$; With CMV of $21.6 \%, 20.0 \%$, $17.6 \%$, and $14.0 \%$. Particularly for PVY, increasing the spray concentration, disease rate has not markedly reduced. In addition, preventing viral infection, Ningnanmycin inhibits the development, multiplying, and moving of viruses in the plants, from infected leaves to later developing leaves lead to a reduction in harmful symptoms on the leaf. It shows that increasing the concentrated treatments from 1.0 to 2.5 times, the disease index of CMV decreases from $16.8 \%$ to $8.8 \%$; TNRV: $45.5 \%$ to $21.2 \%$; and from $35.7 \%$ to $23.7 \%$ for PVY. Particularly, for diseases caused by PVY, Ningnanmycin can not prevent infection of virus into plants, but limits the growth, multiplying, and moving of viruses in tobacco plants.

The viral effect control of Ditacin 8SL increases gradually with raising the concentration, reaches high efficiency at the concentration of 2.5\%. For PVY, when spray at concentrations of 1 times, 1.5 times, 2.0 times, and 2.5 times, the prevention efficiency increases by $30.3 \%, 35.8 \%, 44.6 \%$, and $53.8 \%$, respectively; With TNRV of $22.4 \%, 37.1 \%, 47.5 \%$, and $63.8 \%$. For the CMV, spray at a concentration of 1 time has a control effect of $27.8 \%$ and 2.5 times increasing to 62.1\%. About statistics, the effectiveness against PVY, TNRV, and CMV at a concentration of 2.5 times is equivalent to 2.0 times at a level of $95 \%$, and is significant difference when treats at concentrations of $1-1.5$ times. The treatment concentrations are significantly different from the control.

Residues of Ningnanmycin: The results of residue analysis show that spraying Ditacin 8SL at a concentration of 1 time and 1.5 times is no residue in the leaf samples of $\mathrm{C}$ and $\mathrm{B}$. When spray at 2.0 times and 2.5 times appears residue in leaf samples ranging from 0.01 to $0.02 \mathrm{mg} / \mathrm{kg}$, but is lower than the allowable residue threshold $(0.1-1 \mathrm{mg} / \mathrm{kg}) \mathrm{according}$ to standards of China.

Table 1: Concentrated Treatment of Ditacin 8SL for effectie control of viral diseases and residues on tobacco

\begin{tabular}{|c|c|c|c|c|c|c|c|c|c|c|c|}
\hline \multirow{2}{*}{$\begin{array}{c}\text { Concentrated } \\
\text { Treatment } \\
\text { (times) }\end{array}$} & \multicolumn{3}{|c|}{ PVY (\%) } & \multicolumn{3}{|c|}{ TNRV (\%) } & \multicolumn{3}{|c|}{ CMV (\%) } & \multicolumn{2}{|c|}{ Residue (mg/kg) } \\
\hline & IN & DI & EC & IN & DI & EC & IN & DI & EC & Leaf $C$ & Leaf B \\
\hline 1.0 & 44.3 & $35.7^{\mathrm{b}}$ & 30.3 & 55.7 & $45.5^{\mathrm{b}}$ & 22.4 & 21.6 & $16.8^{\mathrm{b}}$ & 27.8 & 0.0 & 0.0 \\
\hline 1.5 & 43.0 & $32.9^{\mathrm{bc}}$ & 35.8 & 45.3 & $36.8^{\mathrm{bc}}$ & 37.1 & 20.0 & $15.2^{\mathrm{bc}}$ & 34.9 & 0.0 & 0.0 \\
\hline 2.0 & 44.0 & $28.4^{\mathrm{cd}}$ & 44.6 & 37.4 & $30.8^{c}$ & 47.5 & 17.6 & $12.1^{\mathrm{cd}}$ & 48.1 & 0.01 & 0.01 \\
\hline 2.5 & 43.0 & $23.7^{\mathrm{d}}$ & 53.8 & 34.4 & $21.2^{\mathrm{c}}$ & 63.8 & 14.0 & $8.8^{\mathrm{d}}$ & 62.1 & 0.01 & 0.02 \\
\hline Control & 70.1 & $51.2^{\mathrm{a}}$ & & 68.0 & $58.6^{\mathrm{a}}$ & & 19.7 & $23.3^{\mathrm{a}}$ & & & \\
\hline Everage $^{*}$ & & 34.4 & 41.1 & & 38.6 & 42.1 & & & 43.1 & & \\
\hline $\mathrm{CV} \%$ & & 10.3 & & & 11.6 & & & 15.2 & & & \\
\hline $\begin{array}{l}\text { Critical Value for } \\
\text { Comparison }\end{array}$ & & 6.68 & & & 8.8 & & & 4.4 & & & \\
\hline
\end{tabular}

Note: *1,0: Spray concentration of the manufacturer, IN: Disease incidence, DI: Disease index, and EC: Effective control

\section{- Sat 4SL (Cytosinpeptidemycyn)}

Sat 4SL (Cytosinpeptidemycyn) is effective in preventing diseases of PVY, TNRV, and CMV. The effectiveness of prevention increases gradually with increasing concentration. For the TNRV, increasing the spray concentration from 1.0 to 2.5 times increases the prevention efficiency from $30.2 \%$ to $43.6 \%$ and an average of $38 \% ; 19.9-41.8 \%$ and an average: $32.7 \%$ with CMV. For PVY, the prevention effectiveness of the agent raises from 5.5\% to $46.3 \%$ and an average of $31.2 \%$ when the spray concentration from 1.0 to 2.5 times. In the experimental concentrations, spraying at $2.0-2.5$ times have high effectiveness against PVY, TNRV, CMV, and have a statistically significant difference compared to other treatments at $95 \%$ level. 
Increasing the spray concentrations of Sat 4SL also increases the plant's resistance, inhibits the multiplying, and moving of virus in the tobacco plant leads to a decrease in disease incidence and disease index on the young leaves. For example, with PVY, increasing the spray concentration from 1.0 to 2.5 times, the disease index reduces from $48.4 \%$ to 27.5\%, TNRV: $40.9 \%$ to $33.5 \%$, and CMV decreases from $18.6 \%$ to $13.5 \%$. Tobacco plants are treated with viral virucides have a lower disease incidence than untreated tobacco plants. For the PVY, antiviral-treated tobacco plants have disease incidence ranging from $41.8-67.0 \%$ and control 70.1\%, TNRV: $43.2-48.4 \%$ (control: $68 \%$ ), and CMV: $14.8-23.1 \%$ (control: $19.7 \%$ ). Those show that Sat 4SL has the effect of inhibiting the infection and biosynthesis of the virus after spraying. However, the inhibitory effect of the drug with each virus species is different at the different concentrations. Spray concentration of 2.5 times tends to increase the disease rate with PVY, the TNRV at $2.0-2.5$ times, except for CMV, the disease incidence increases with raising spray concentrations from $14.8 \%$ (1 times) to $23.1 \%$ at the concentration of 2.0 times, and higher than the control (19.7\%).

Currently, in Vietnam, there is no method to determine the active ingredient of Cytosinpeptidemycyn, so we do not analyze residues in dry leaf tobacco. Sat 4SL is a biological agent, has less toxicity and a short isolation time (2 days), and the similar to Ningnanmycin will have very little residue in the dry leaf.

Table 2: Concentrated Treatment of Sat 4SL for effectie control of viral diseases and residues on tobacco

\begin{tabular}{|c|c|c|c|c|c|c|c|c|c|}
\hline \multirow{2}{*}{$\begin{array}{l}\text { Concentrated } \\
\text { Treatment } \\
\text { (times) }\end{array}$} & \multicolumn{3}{|c|}{ PVY (\%) } & \multicolumn{3}{|c|}{ TNRV (\%) } & \multicolumn{3}{|c|}{ CMV (\%) } \\
\hline & IN & DI & EC & IN & DI & EC & IN & DI & EC \\
\hline 1.0 & 67,0 & $48,4^{\mathrm{a}}$ & 5,5 & 45,5 & $40,9^{\mathrm{b}}$ & 30,2 & 14,8 & $18,6^{\mathrm{b}}$ & 19,9 \\
\hline 1.5 & 46,3 & $36,0^{\mathrm{b}}$ & 29,7 & 43,2 & $36,3^{\mathrm{bc}}$ & 38,0 & 17,9 & $16,0^{\mathrm{bc}}$ & 31,3 \\
\hline 2.0 & 41,8 & $29,0^{\mathrm{bc}}$ & 43,4 & 48,4 & $35,2^{\mathrm{c}}$ & 40,0 & 23,1 & $14,5^{\mathrm{c}}$ & 37,7 \\
\hline 2.5 & 49,5 & $27,5^{\mathrm{c}}$ & 46,3 & 48,4 & $33,1^{\mathrm{c}}$ & 43,6 & 19,4 & $13,5^{\mathrm{c}}$ & 41,8 \\
\hline Control & 70,1 & $51,2^{\mathrm{a}}$ & & 68,0 & $58,6^{\mathrm{a}}$ & & 19,7 & $23,3^{\mathrm{a}}$ & \\
\hline Everage & & 35,2 & 31,2 & & 36,6 & 38,0 & & 15,7 & 32,7 \\
\hline $\mathrm{CV} \%$ & & 10,5 & & & 6,4 & & & 12,8 & \\
\hline $\begin{array}{l}\text { Critical Value for } \\
\text { Comparison }\end{array}$ & & 7,6 & & & 4,8 & & & 4,1 & \\
\hline
\end{tabular}

- Thuốc Exin 4.5SC (Salicylic acid)

Table 3: Concentrated Treatment of Exin 4.5SC for effectie control of viral diseases and residues on tobacco

\begin{tabular}{|c|c|c|c|c|c|c|c|c|c|}
\hline $\begin{array}{c}\text { Concentrated } \\
\text { Treatment } \\
\text { (times) }\end{array}$ & \multicolumn{3}{|c|}{ PVY (\%) } & \multicolumn{3}{c|}{ TNRV (\%) } & \multicolumn{3}{c|}{ CMV (\%) } \\
\cline { 2 - 11 } & IN & DI & EC & IN & DI & EC & IN & DI & EC \\
\hline 1.0 & 51.1 & $38.9^{\mathrm{b}}$ & 24.1 & 58.0 & $50.3^{\mathrm{ab}}$ & 14.2 & 29.5 & $21.4^{\mathrm{a}}$ & 8.2 \\
\hline 1.5 & 42.1 & $30.5^{\mathrm{bc}}$ & 40.4 & 52.6 & $41.1^{\mathrm{bc}}$ & 30.0 & 32.6 & $20.6^{\mathrm{a}}$ & 11.4 \\
\hline 2.0 & 46.2 & $28.8^{\mathrm{c}}$ & 43.8 & 42.9 & $35.4^{\mathrm{c}}$ & 39.5 & 22.0 & $14.5^{\mathrm{b}}$ & 37.7 \\
\hline 2.5 & 46.2 & $25.8^{\mathrm{c}}$ & 49.6 & 36.6 & $30.4^{\mathrm{c}}$ & 48.2 & 16.1 & $11.2^{\mathrm{b}}$ & 52.0 \\
\hline Control & 70.1 & $51.2^{\mathrm{a}}$ & & 68.0 & $58.6^{\mathrm{a}}$ & & 19.7 & $23.3^{\mathrm{a}}$ & \\
\hline Everage & & 31.0 & 39.5 & & 39.3 & 33.0 & & 16.9 & 27.3 \\
\hline CV\% & 14.4 & & & 14.8 & & & 15.3 & \\
\hline Critical Value for Compariso & 9.5 & & & 11.9 & & & 5.2 & \\
\hline
\end{tabular}

Similar to Ditacin 8SL and Sat 4SL, Exin 4.5SC is effective against viral diseases on tobacco. The effect of Exin 4.5SC increases with spray concentrations. For PVY, the prevention effectiveness of the agent increases from $24.1 \%$ to $49.6 \%$, an average of $39.5 \%$; TNRV: $14.2 \%$ to $48.2 \%$, an average $33 \%$; and CMV: increases from $8.2 \%$ to $52.0 \%$ and an averaged $27.3 \%$ when spraying at concentrations of from 1.0 to 2.5 times. The highest effective control of PVY sprays at a concentration of $1.5-2.5$ times, while for TNRV and CMV are at $2.0-2.5$ times. Those concentrations are significant statistics compared to control of $95 \%$ level.

Increasing the spray concentrations lead to an increase the effectiveness of the prevention of the virus. Increasing the spray concentration from 1.0 - 2.5 times, the disease index of PVY reduces from $38.9 \%$ to $25.8 \%$ compared to the control of $51.2 \%$; TNRV: $50.3 \%$ to $30.4 \%$ (control of 58.6\%). For CMV, the disease index decreases from $21.4 \%$ to $11.2 \%$ 
compared to the control of $23.3 \%$. About statistics: The spray concentrations of Sat 4.5SC against PVY have a statistically significant difference with control; TNRV: spray concentration from $1.5-2.5$ times is a significant difference compared to control, and 1.0 times is not significantly different compared to control. For CMV, spraying at concentrations from 2 - 2.5 times is a significant difference from control, whereas at 1.0 to 1.5 times are not different from control. The effect control is highest at the spray concentration of $2.0-2.5$ times with PVY, TNRV, and CMV.

In addition to inhibiting the growth of virus in plants, Salicylic acid has the effect of preventing infection of PVY and TNRV into plants and disease rate increases with concentrated treatment of drugs. When increasing the concentration from 1.0 to 2.5 times, the incidence of TNRV decreases from 58.0\% to 36.6\% compared with the control 70.1\%, with PVY: $51.1 \%$ to $42.1 \%$ (control: $68 \%$ ). Particularly, for CMV, tobacco plants are treated at a concentration of $1.0-2.0$ have a disease incidence from 22.0 to $32.6 \%$ and higher than the control without spraying (19.7\%). Salicylic acid is a non-toxic plant and does not require isolation in agricultural production. Increasing the spray concentration from 1.0 to 2.5 times does not affect the growth and development of tobacco plants.

\subsection{Effective control against tobacco virus disease of a mixture of antiviral virucides and insecticide in Bac Giang province in spring 2021.}

\section{- Effective control for tobacco virus disease}

Table 4: Effective control against virus diseases of a mixture of antiviral virucides and insecticide

\begin{tabular}{|c|c|c|c|c|c|c|c|c|c|c|c|c|}
\hline \multirow{2}{*}{ Treament } & \multicolumn{3}{|c|}{ PVY (\%) } & \multicolumn{3}{|c|}{ TNRV (\%) } & \multicolumn{3}{|c|}{ CMV (\%) } & \multicolumn{3}{|c|}{ TMV (\%) } \\
\hline & IN & DI & $\mathbf{E C}$ & IN & DI & EC & IN & DI & $\mathbf{E C}$ & $\mathbf{I N}$ & DI & $\mathbf{E C}$ \\
\hline CT1 & $21,0^{\mathrm{b}}$ & $15,7^{\mathrm{b}}$ & 34,3 & $30,7^{\mathrm{bc}}$ & $24,0^{\mathrm{b}}$ & 35,8 & $23,0^{\mathrm{ab}}$ & $12,5^{\mathrm{b}}$ & 36,5 & 0,0 & 0,0 & 100 \\
\hline $\mathrm{CT} 2$ & $21,2^{\mathrm{b}}$ & $16,1^{\mathrm{b}}$ & 32,6 & $29,3^{c}$ & $23,4^{\mathrm{b}}$ & 37,4 & $24,7^{\mathrm{ab}}$ & $13,0^{\mathrm{b}}$ & 34,0 & 0,3 & 0,1 & 92,3 \\
\hline CT3 & $18,6^{\mathrm{b}}$ & $14,7^{\mathrm{b}}$ & 38,5 & $29,7^{\mathrm{c}}$ & $22,9^{\mathrm{b}}$ & 38,8 & $18,0^{\mathrm{b}}$ & $11,7^{\mathrm{b}}$ & 40,6 & 0,0 & 0,0 & 100 \\
\hline CT4 & $28,9^{\mathrm{a}}$ & $22,3^{a}$ & 6,7 & $39,7^{\mathrm{a}}$ & $33,8^{\mathrm{a}}$ & 9,6 & $21,7^{\mathrm{ab}}$ & $14,8^{\mathrm{ab}}$ & 24,9 & 0,5 & 0,4 & 100 \\
\hline CT5 & $25,7^{\mathrm{ab}}$ & $18,6^{\mathrm{ab}}$ & 22,2 & $38,7^{\mathrm{ab}}$ & $32,4^{\mathrm{a}}$ & 13,4 & $23,3^{\mathrm{ab}}$ & $15,1^{\mathrm{ab}}$ & 23,4 & 0,0 & 0,0 & 100 \\
\hline Control & $32,4^{\mathrm{a}}$ & $23,9^{\mathrm{a}}$ & & $43,0^{\mathrm{a}}$ & $37,4^{\mathrm{a}}$ & & $28,3^{\mathrm{a}}$ & $19,7^{\mathrm{a}}$ & & 2,4 & 1,4 & \\
\hline \multicolumn{4}{|c|}{ Residue level of Ningnanmycin (mg/kg) } & \multicolumn{5}{|c|}{0,02} & \multicolumn{4}{|c|}{ Allowable threshold: $0,1-1 \mathrm{mg} / \mathrm{kg}$} \\
\hline \multicolumn{4}{|c|}{ Residue level of imidacloprid (mg/kg) } & \multicolumn{4}{|c|}{$3,13-4,33$} & \multicolumn{5}{|c|}{ Allowable threshold: $0,02-5 \mathrm{mg} / \mathrm{kg}$} \\
\hline
\end{tabular}

Note: CT1: Ditacin 8SL + Confidor 100SL, CT2: Sat 4SL + Confidor 100SL, CT3: Exin 4.5SC + Confidor 100SL, CT4: Ditacin 8SL + Exin 4.5SC + Confidor 100SL + foliar fertilizer, CT5: Sat 4SL + Exin 4.5EC + Confidor 100SL + foliar fertilize.

The results of study show the spray treatments periodically every 6 days/a times from stage $3-4$ leaves/plant to 1 week before cutting-top have effective control with virus diseases on tobacco plants in Bac Giang. The effective control of CT1, CT2, and CT3 is the highest ranging from 32.6 to $40.6 \%$, following by CT5 (13.4 - 23.4\%), and the lowest is CT4 (6.7 - 24.9\%). Particularly, with TMV, all treatments are high prevention effectiveness ranging from 92.3 to $100 \%$.

The spray treatments have the effect of inhibiting the infection, development, and damage of virus in tobacco plants lead to a reduction in harmful symptoms on leaf. Those show that disease incidence and disease index of the treated tobacco plants are lower than the control. For example, the incidence of PVY of the spray treatments ranges from 18.6 to 28.9\% compared to the control of 32.4\%; TNRV: 29.3 - 39.7\% (control: $42.0 \%$ ); For CMV, the disease incidence is from 18.0 to $24.7 \%$ and control: $28.3 \%$. Regarding the degree of harm, the disease index of PVY ranges from 14.7 to $22.3 \%$ compared to control 23.9\%; TNRV: 22.9 - 33.8\% (control: 37.4\%), and CMV: 11.7 to $15.1 \%$ (control 19.7\%). For TMV, the disease incidence is $0.5 \%$ and while control is $2.4 \%$.

In the experimental treatments, CT1 (Ditacin 8SL + Confidor 100SL), CT2 (Sat 4SL + Confidor 100SL), and CT3 (Exin 4.5SC + Confidor 100SL) can effectively inhibit the invasion and growth of PVY, TNRV, and CMV in tobacco plants. Those treatments are no statistical difference but are significantly different from the control. In while, for CT4 (Ditacin 8SL + Exin 4.5SC + Confidor 100SL + Foliar fertilizer) and CT5 (Sat 4SL + Exin 4.5EC + Confidor 100SL + Foliar fertilizer) have the effect of reducing disease incidence and disease index in experimental fields, but not significantly different from the control. Particularly, for CMV, CT3 has the lowest rate of infected plants (18\%) and disease index $(11.7 \%)$ but is significantly different from the control. Other treatments reduce the disease incidence but are not different from the control.

The results of the analysis residue show the dry leaf tobacco have residues of Ningnanmycin reaching $0.02 \mathrm{mg} / \mathrm{kg}$ compared to the allowable threshold of China from $0,1-1 \mathrm{mg} / \mathrm{kg}$. For Imidacloprid, it ranges from 3.13 to $4.33 \mathrm{mg} / \mathrm{kg}$ (Max residue according to the standards of Vietnam, China and Coresta is $5 \mathrm{mg} / \mathrm{kg}$ ). Thus, periodic spraying to prevent 
tobacco virus diseases from stage planting to 1 week before cutting the tops have residues in dry leaf but do not exceed the allowable threshold.

\section{- Effective control for tobacco virus disease on tobacco yield and quality}

Fresh leaf yield: The spray treatments have fresh leaf yield increasing from 10.3 to $39.7 \%$ compared to the control. In which, CT1 and CT3 have the highest yield (38.9 - 39.7\%), after CT2 (35.2\%), and the lowest is CT4 (10.3\%). Statistically, fresh leaf yield of CT1, CT2, and CT3 is not significantly different at the 95\% level, but the difference is significant with other treatments and control. For CT4 and CT5, the yield of fresh leaves is from $10.3 \%$ to $18.8 \%$, higher than the control, but there is no statistically significant difference compared with control.

- Dry leaf yield: CT1, CT2, and CT3 are effective in disease prevention and have the highest dry leaf yield, reaching 1.52 - 1.67 tons/ha, increasing from $32.2 \%$ to $38.2 \%$ compared to the control. Particularly, CT4 and CT5 have dry leaf yield increasing from 18.8 to $19.5 \%$, but there is no significant difference with the control at the $95 \%$ level.

- Grade of dry leaf: CT1, CT2, and CT3 have the highest percentage of grade $1+2$ and reach ranging from 63.8 to $65.6 \%$, next to CT4 and CT5 $(54.7-56.2 \%)$, and the control only reaches $40.6 \%$. For the grade of 4 , CT1, CT2, and CT3 have a low percentage of grade $4(0.8-5.9 \%)$, then CT4 and CT5 $(11.2-15.1 \%)$, and the control has the highest percentage of grade 4 is $30.3 \%$. The high proportion of grade 4 reduces the use-value and economic-value in tobacco production.

So after two year of testing antiviral drugs (in 2020 and 2021) in the field conditions in Bac Giang province, Ditacin 8SL, Exin 4.5SC, and Sat 4SL have effective control of TMV, CMV, PVY, and TNRV. Spray Treatments of combination viral agents and insecticides (Confidor 100SL) in 2021 have more effective control than only spraying antiviral agents or insecticides. For example, using only virucides, the effectiveness control of Exin $4.5 \mathrm{SC}$ ranges from 8.2 to $24.1 \%$, Ditacin 8SL: 22.4 to $30.3 \%$ and Sat 4SL from $5.5-30.2 \%$, in while, spraying the mixture of Exin $4.5 \mathrm{SC}+$ Confidor 100SL has a prevention effectiveness of 38.5 - 100\%, Ditacin 8SL + Confidor 100SL: 34.3 - 100\%, and Sat 4SL + Confidor 100SL is $32.6-92.3 \%$.

Table 5: Effective control for tobacco virus disease on tobacco yield and quality of antiviral virucides

\begin{tabular}{|c|c|c|c|c|c|c|c|}
\hline \multirow{2}{*}{ Treament } & \multirow{2}{*}{$\begin{array}{c}\text { Fresh leaf } \\
\text { yield } \\
\text { (ton/ha) }\end{array}$} & \multirow{2}{*}{$\begin{array}{c}\text { Increase } \\
(\boldsymbol{\%})\end{array}$} & $\begin{array}{c}\text { Dry leaf } \\
\text { yield } \\
\text { (ton/ha) }\end{array}$ & $\begin{array}{c}\text { Increase } \\
(\boldsymbol{\%})\end{array}$ & \multicolumn{3}{|c|}{ Grade (\%) } \\
\cline { 5 - 9 } & $16,4^{\mathrm{a}}$ & 39,7 & $1,67^{\mathrm{a}}$ & 38,2 & 65,5 & 33,6 & 0,9 \\
\hline CT1 & $15,3^{\mathrm{a}}$ & 35,2 & $1,52^{\mathrm{ab}}$ & 32,2 & 65,6 & 33,6 & 0,8 \\
\hline CT3 & $16,2^{\mathrm{a}}$ & 38,9 & $1,61^{\mathrm{a}}$ & 36,0 & 63,8 & 30,3 & 5,9 \\
\hline CT4 & $11,1^{\mathrm{b}}$ & 10,3 & $1,27^{\mathrm{bc}}$ & 18,8 & 54,7 & 34,1 & 11,2 \\
\hline CT5 & $12,2^{\mathrm{b}}$ & 18,8 & $1,28^{\mathrm{bc}}$ & 19,5 & 56,2 & 28,7 & 15,1 \\
\hline Control & $9,9^{\mathrm{b}}$ & & $1,03^{\mathrm{c}}$ & & 40,6 & 29,1 & 30,3 \\
\hline CV\% & 11,9 & & 11.69 & & & & \\
\hline $\begin{array}{l}\text { Critical Value } \\
\text { for Comparison }\end{array}$ & 2.9498 & & 0.29 & & & & \\
\hline
\end{tabular}

To prevent the effectiveness of virus diseases on tobacco plants, we should take some management methods such as: spray anti-viral agents when tobacco plants are not infected or symptoms have not appeared on leaves; Spray agents at least 4 times; Virus species that are transmitted by vectors have to spray in combination with insecticides and virucides; And if the plant grows slowly, it can spray in combination with foliar fertilizer to increase the growth of tobacco and increase tobacco resistance. Results of our study with Ningnamycin, Cytosinpeptidemycyn, and Salicylic acid are similar to Zainab F. Al-Hashimi et al., 2010 (spraying in combination with insecticides and virucides); increasing plant resistance, limits viral infection and growth in plants of LeiZhao et al., 2015, and disease control is effective when spraying antiviral agents before infective plants of Zainab F. Al-Hashimi et al., 2010.

\section{CONCLUSION}

Antiviral agents are effective against viral diseases on tobacco plants. The effective control of Ditacin 8SL ranges 22.4 - 30.3\%; Sat 4SL: 5.5 - 30.2\%, and Exin 4.5SC: 8.2 - 24.1\%. Spraying a mixture of antiviral agents and insecticides gives higher efficiency than a kind. Spray Ditacin 8SL + Confidor 100SL have effectiveness from 34.3 to $100 \%$; 32.6 92.3 with Sat 4SL + Confidor 100SL, and 38.5 - 100\% with Exin 4.5SC + Confidor 100SL. The spray treatments, dry leaf yield are higher than the control without spraying from $18.8-38.2 \%$. Residue pesticides of dry tobacco leaves are little and do not exceed the allowable residue threshold. 


\section{ACKNOWLEDGMENT}

Authors are thankful to the Ministry of Industry and Trade, Vietnam Tobacco Corporation, Vietnam Tobacco Institute, and the Branch of Vietnam Tobacco Institute in Bac Giang for performing this study.

\section{CONFLICT OF INTEREST}

The authors declared no conflict of interest.

\section{FINANCIAL SUPPORT}

The study was supported the finance of the Ministry of Industry and Trade, Vietnam

\section{REFERENCES}

[1] Mengnan An, Xiuxiang Zhao, Tao Zhou, Guanzhong Wang, Zihao Xia, Yuanhua Wu. 2019. A Novel Biological Agent Cytosinpeptidemycin Inhibited the Pathogenesis of Tobacco Mosaic Virus by Inducing Host Resistance and Stress Response. J Agric Food Chem, 2019 Jul 10;67(27):7738-7747. PMID: 31199650. DOI: 10.1021/acs.jafc.9b02662.

[2] Boualem, A., Dogimont, C. \& Bendahmane, A. 2016. The battle for survival between viruses and their host plants. Curr. Opin. Virol. 17, 32-38, https://doi.org/10.1016/j.coviro.2015.12.001.

[3] Nguyen Van Chin, Do Thi Thuy, Phung Thi Hay, Nguyen Van Van, Tao Ngoc Tuan, Nguyen Quoc Tuan, and Nguyen Van Cuong. 2021. Estimating The Effective Control of Ditacin 8 SL, and Sat 4SL with Tobacco Mosaic Virus (TMV), Cucumber Mosaic Virus (CMV), and Potato Virus Y (PVY) on Tobacco Plants. Journal of Science and Technology, Vol. 06, Issue 03, May-June 2021, pp80-87.

[4] Hoseong Choi, Yeonhwa Jo, Won Kyong Cho, Jisuk Yu, Phu-Tri Tran, Lakha Salaipeth, Hae-Ryun Kwak, HongSoo Choi and Kook-Hyung Kim, 2020. Identification of Viruses and Viroids Infecting Tomato and Pepper Plants in Vietnam by Metatranscriptomics. Int. J. Mol. Sci. 2020, 21(20), 7565; https://doi.org/10.3390/ijms21207565.

[5] Florence Faurez, Thomas Baldwin, Michel Tribodet, and Emmanuel Jacquot. 2012.Identification of new Potato virus Y (PVY) molecular determinants for the induction of vein necrosis in tobacco. Mol Plant Pathol. 2012 Oct; 13(8): 948-959. PMCID: PMC6638754. https://doi.org/10.1111/j.1364-3703.2012.00803.

[6] German TL, Ullman DE, Moyer JW. 1992. Tospoviruses: diagnosis, molecular biology, phylogeny, and vector relationships. Annu Rev Phytopathology 30:315-34

[7] Palukaitis, P. \& García-Arenal, F. 2003. Cucumoviruses. Adv. Virus Res. 62, 241-323.

[8] Channarong Seepiban, Oraprapai Gajanandana, Tipvadee Attathom, Supat Attathom, 2011. Tomato necrotic ringspot virus, a new tospovirus isolated in Thailand. Arch Virol. 2011 Feb;156(2):263-274. PMID: 21104282. DOI: 10.1007/s00705-010-0856-0.

[9] Ziwen Wang, Anzheng Feng, Mingbo Cui, Yuxiu Liu, Lizhong Wang, Qingmin Wang. 2012. First Discovery and Structure-Activity Relationship Study of Phenanthroquinolizidines as Novel Antiviral Agents against Tobacco Mosaic Virus (TMV). PLOS ONE 7(12) 2012, e52933. PMID: 23285230. DOI:10.1371/journal.pone.005293.

[10] Yueyan Yin, Kuanyu Zheng, Jiahong Dong, Qi Fang, Shiping Wu, Lishuang Wang, and Zhongkai Zhang, 2014. Identification of a new tospovirus causing necrotic ringspot on tomato in China. Virol J. 2014; 11: 213. PMID: 25465801. Published online 2014 Dec 3. DOI: 10.1186/s12985-014-0213-0.

[11]Zainab F. Al-Hashimi; Ragad N. Al-Khashab; Nabeel A. Kassim. 2010.Impact of salicylic acid and liquid fertilizers on the productivity of PVY-infected potato plants.Rafidain Journal of Science, 2010, Volume 21, Issue 5, Pages 7382. DOI:10.33899/rjs.2010.37006.

[12]Zhao L, Feng C, Hou C, Hu L, Wang Q, Wu Y (2015). First Discovery of Acetone Extract from Cottonseed Oil Sludge as a Novel Antiviral Agent against Plant Viruses. PLoS ONE 10 (2): e0117496. doi:10.1371/journal.pone.0117496. 